\title{
STUDI KASUS: ANALISIS KESALAHAN SISWA DALAM MENYELESAIKAN SOAL CERITA MATEMATIKA MATERI SISTEM PERSAMAAN LINEAR TIGA VARIABEL DI SMA NEGERI 1 CERME
}

\author{
Heni Baskorowati \\ Jurusan Matematika, Program Studi Pendidikan Matematika, FMIPA, Universitas Negeri Surabaya \\ Email: baskorowatiheni@mhs.unesa.ac.id \\ Pradnyo Wijayanti \\ Jurusan Matematika, Program Studi Pendidikan Matematika, FMIPA, Universitas Negeri Surabaya \\ Email: pradnyowijayanti@unesa.ac.id
}

\begin{abstract}
Abstrak
Penelitian ini didasari atas banyaknya kesulitan yang dihadapi siswa dalam mengerjakan soal cerita matematika menyebabkan terjadinya kesalahan. Kesalahan siswa harus segera dipecahkan agar tidak terulang dan mempengaruhi hasil belajar. Pemecahan ini dapat dilakukan dengan cara mengetahui dimana letak kesalahan yang terjadi, jenis kesalahan yang dilakukan dan faktor penyebabnya. Penelitian ini menggunakan metode deskriptif-kualitatif. Penelitian ini bertujuan untuk menganalisis letak dan jenis kesalahan serta faktor yang menyebabkan kesalahan yang dilakukan siswa menggunakan tahapan pemecahan pemecahan masalah Polya. Teknik pengambilan data menggunakan metode tes tulis dan wawancara. Tes tulis yang diberikan berupa soal cerita matematika pada materi sistem persamaan linear tiga variabel. Subjek penelitian yaitu 3 siswa dipilih dari 36 siswa XI IPA4 SMA Negeri 1 Cerme. Subjek penelitian dipilih berdasarkan banyaknya kesalahan yang dilakukan pada saat tes tulis, kemudian diwawancarai. Hasil penelitian mengindikasikan bahwa dalam mengerjakan soal cerita dengan materi sistem persamaan linear tiga variabel, terjadi kesalahan pada masing-masing indikator dalam tahapan pemecahan masalah Polya. Kesalahan terbanyak terjadi pada tahap pemahaman soal dengan presentase sebesar 42,23\%; perencanaan penyelesaian masalah sebanyak $15,94 \%$; pelaksanaan rencana penyelesaian sebanyak 16,73\%, dan kesalahan dalam memeriksa kembali jawaban sebanyak $25,10 \%$. Jenis kesalahan siswa yaitu kesalahan konsep, prinsip, dan operasi. Faktor penyebab kesalahan siswa yaitu tidak memahami makna soal, lemahnya pemahaman konsep, tidak fokus dalam pengerjaan, lingkungan dan cara belajar siswa. Dari letak, jenis dan faktor penyebab kesalahan yang diperoleh pada penelitian ini dapat digunakan oleh pendidik sebagai pertimbangan dalam merencanakan pembelajaran agar kesalahan serupa tidak terulang.
\end{abstract}

Kata kunci: analisis, kesalahan, pemecahan masalah Polya, soal cerita, spltv.

\section{Abstract}

This research is motivated by the number of difficulties students faced while solving mathematics story problem which causes errors. Student's error needs to be solved immediately to not affecting the learning result. To solve them, we needs to identified location of the errors occur, types of mistakes are made, and what are the causes. This research use a qualitative-descriptive approach. This research aims to analyze the location, type of errors, and the causes using Polya's problem-solving steps. To collect data, this research using written test and interview methods. The written test is in the form of mathematics story problem involving the linear equation of three variables. The research subjects were 3 of 36 students from class $11^{\text {th }}$ Science 4 State Highschool of Cerme. Research subject is chosen based on the number of errors made during the written test then interviewed. The result of this research shows that in order to solve problems, errors occurs on each Polya's problem-solving steps indicators. Most error occurs in understanding the problem which is by $42,23 \%$; devising a plan $15,94 \%$; carrying out the plan $16,73 \%$; and looking back $25,10 \%$. The type of errors made by students were concept error, principle error, and operation error. The factors are not understand the problem, low concept, not focus, cognitive factors, and their learning environment. The result of this research can be used for teachers to make their teaching plan to avoid the same error occurs.

Keywords: analysis, errors, story problems, Polya's problem-solving, spltv. 


\section{PENDAHULUAN}

Peran Matematika sangat penting dalam kehidupan. Di Sekolah, siswa dituntut untuk mahir dalam matematika sebagai dasar untuk menanggapi perkembangan pesat ilmu pengetahuan dan teknologi. Hal ini dikarenakan matematika merupakan dasar ilmu dari semua cabang ilmu pengetahuan dan teknologi. Salah satu tujuan mempelajari matematika di sekolah yaitu untuk mengembangkan keterampilan pemecahan masalah siswa. Namun nyatanya, ada banyak siswa yang kesulitan dalam mempelajari matematika. Banyak siswa merasa kesulitan untuk memecahkan soal matematika, terutama yang diterapkan pada masalah kehidupan sehari-hari.

Rahardjo dan Waluyati (2011) berpendapat bahwa soal cerita matematika adalah soal matematika yang berkaitan dengan kehidupan, yang bertujuan untuk ditemukan solusi dalam kalimat matematika. Persoalan matematika baik dalam bentuk cerita maupun non-cerita dapat digunakan untuk menilai kemampuan siswa dalam mata pelajaran matematika. Dalam penyelesaian soal cerita, siswa harus memiliki keterampilan memecahkan masalah. Penyelesaian soal cerita matematika bukan hanya untuk mendapatkan hasil jawaban, tapi siswa mampu mengguasai proses berpikir atau tahapan untuk memperoleh jawaban tersebut.

Pemberian soal cerita bermanfaat untuk mengembangkan proses berpikir siswa secara terusmenerus dengan tujuan untuk meraih standar kompetensi yang telah ditetapkan, serta melatih siswa untuk menyelesaikan persoalan matematika dalam kehidupan sehari-hari. Siswa juga diharuskan untuk menyelesaikan masalah menggunakan kemampuannya dalam pemahaman, perancangan, dan penyelesaian soal cerita tersebut. Fakta di lapangan mengungkapkan bahwa pada mata pelajaran matematika, siswa banyak mengalami kesulitan dalam memecahkan soal cerita. Kesulitan yang dihadapi siswa dalam menyelesaikan soal cerita matematika dapat mengakibatkan terjadinya kesalahan. Hal ini disebabkan pembelajaran matematika di kelas sudah terbiasa menggunakan metode ceramah sehingga siswa menerima pelajaran dengan pasif dan cenderung menghafal konsep daripada memahami konsep. Akibatnya apabila siswa diberikan permasalahan yang berlainan dengan contoh yang diberikan guru, siswa akan mengalami kesulitan, sehingga terjadi kesalahan dalam memecahkan permasalahan tersebut.

Menurut Loc dan Hoc (2014:1-2), kesalahan didefinisikan sebagai penyimpangan dari akurasi atau ketidaktepatan dalam menyajikan solusi soal. Dalam memecahkan permasalahan matematika, kesalahan terjadi karena adanya hambatan dalam proses pemecahannya. Kesalahan yang dilakukan oleh siswa dapat mendefinisikan sejauh mana pemahaman mereka terhadap materi tersebut. Pemahaman siswa terhadap suatu materi juga mempengaruhi kemampuan mereka dalam mengerjakan soal.

Menurut Polya (1973), pemecahan masalah adalah upaya menemukan solusi dari suatu kesulitan dan mencapai tujuan yang tidak dapat diperoleh dengan segera. Oleh karena itu, pemecahan masalah adalah kegiatan dengan tingkat pengetahuan yang tinggi. Untuk menganalisis proses penyelesaian masalah dalam bentuk soal cerita dapat menggunakan metode pemecahan masalah. Polya (1973) ada empat tahapan pemecahan masalah yaitu memahami masalah (understanding the problem); merencanakan penyelesaian (devising a plan); melaksanakan rencana pemecahan masalah (carrying out the plan); dan pemeriksaan kembali (looking back). Menurut Soedjadi (2000), penyelesaian soal cerita matematika dapat dilakukan dengan tahapan berikut: (1) membaca soal cerita dengan teliti untuk memahami arti setiap kalimat, (2) menyisihkan dan memaparkan apa yang ditanya oleh soal, pengerjaan hitung apa yang diperlukan, (3) membentuk model matematika dari soal, (4) mengerjakan model berdasarkan aturan matematika sehingga memperoleh jawaban soal tersebut, (5) mengembalikan jawaban model matematika kepada jawaban soal aslinya. Tahap-tahap pemecahan masalah yang dicetuskan oleh George Polya merupakan metode mendasar untuk memilah informasi yang relevan. Dalam penelitian ini peneliti menggunakan tahapan pemecahan masalah Polya karena tahap tersebut menyajikan kerangka kerja yang tersusun rapi untuk memecahkan masalah. Beberapa hasil penelitian yang telah dilakukan sebelumnya menunjukkan bahwa penyelesaian dengan menggunakan tahapan Polya sangat efektif. Maka peneliti menggunakan tahapan Polya untuk mengetahui kesalahan yang dilakukan siswa untuk menyelesaikan masalah matematika dengan pokok bahasan SPLTV.

Berdasarkan kurikulum Nasional, aljabar merupakan salah satu materi matematika yang harus dipelajari pada tingkatan pendidikan SMA/MA. Menurut kementrian pendidikan dan kebudayaan hasil ujian nasional tahun 2018 terkait aljabar mengalami penurunan dari tahun sebelumnya yaitu dari $43,75 \%$ menjadi $39,48 \%$. Pada tahun 2019 terjadi sedikit peningkatan meskipun belum bisa dikatakan memuaskan yaitu $45,49 \%$. Salah satu materi aljabar di SMA yang berkaitan erat dengan permasalahan sehari-hari adalah Sistem Persamaan Linear Tiga Variabel (SPLTV). SPLTV yang dipelajari pada satuan pendidikan SMA/MA merupakan pengembangan dari materi Sistem Persamaan Linear Dua Variabel (SPLDV) pada SMP.

Utami dan Zulkarnaen (2019) menyatakan banyak siswa yang melakukan kesalahan saat mengerjakan soal cerita SPLTV karena mengalami kesulitan dalam mencerna bahasa yang terdapat pada soal serta lemah dalam memanipulasi soal matematika. Hal ini sejalan dengan Kuswanti (2018) kesalahan yang paling sering dilakukan siswa saat mengerjakan masalah SPLTV adalah mentransfoemasi masalah dan menuliskan jawaban akhir sebab siswa tidak memahami informasi penting yang ada pada soal. Hasil wawancara dengan salah satu guru matematika di SMAN 1 Cerme menunjukkan bahwa sebagian besar siswa di kelas X, XI dan XII masih mengalami kesulitan apabila dihadapkan dengan soal cerita. Kesalahan yang sering terjadi diantaranya kesalahan dalam berhitung, tidak memahami maksud soal, dan kesalahan konsep. Meskipun siswa telah mempelajari 
sistem persamaan linear dua variabel di SMP, dan sistem persamaan linear tiga variabel di SMA, tidak sedikit siswa yang salah dalam mengerjakan soal yang diberikan. Hal ini dikarenakan soal yang diberikan umumnya berupa soal cerita sehingga siswa sering melakukan kesalahan. Kesalahan yang dilakukan siswa ketika memecahkan soal cerita materi sistem persamaan linear tiga variabel dapat mencerminkan tingkat penguasaan siswa terhadap materi tersebut. Untuk menghindari terulangnya kesalahan dan berdampak negatif pada hasil belajar siswa, kesalahan tersebut perlu dianalisis.

Penelitian ini bertujuan mendeskripsikan letak dan jenis kesalahan yang sering dilakukan siswa ketika memecahkan soal cerita sistem persamaan linear tiga variabel dan apa faktor penyebab terjadinya kesalahan tersebut. Letak kesalahan adalah tempat kesalahan siswa pada tahapan pemecahan soal. Sedangkan jenis kesalahan berhubungan dengan kesalahan dalam mengerjakan hitungan dan konsep pemecahan soal. Dari kemampuan intelektual siswa dalam memecahkan masalah, dapat dilihat faktor apa saja yang menyebabkan kesalahan siswa. Letak, jenis, dan faktor penyebab kesalahan siswa nantinya dapat menjadi acuan bagi pendidik untuk meningkatkan pembelajaran di kelas dan memilih metode pembelajaran yang tepat agar kesalahan-kesalahan tersebut dapat dihindari.

Menurut Sudijono (2011), analisis adalah keahlian seseorang untuk melakukan perincian atau penguraian suatu materi atau peristiwa berdasarkan faktor-faktor yang lebih kecil dan mampu mengartikan hubungan antara faktor-faktor yang satu dan yang lainnya. Rosyidi (2005) berpendapat bahwa kesalahan adalah suatu bentuk penyimpangan dari apa yang diyakini benar atau telah disetujui. Sedangkan menurut Dupe (2015), kesalahan adalah kekeliruan dari situasi yang benar atau penyimpangan dari hal-hal yang disepakati sebelumnya. Sehingga dapat disimpulkan bahwa Analisis kesalahan adalah kegiatan mengamati secara detail tentang penyimpangan atau kekeliruan jawaban dari jawaban yang benar. Jawaban tersebut kemudian dikelompokkan sesuai letak dan jenis kesalahan yang dilakukan untuk memahami hubungan diantara faktor-faktor yang menjadi penyebab kesalahan tersebut sehingga dapat ditemukan solusinya.

Menurut Atim (2008), soal cerita adalah masalah yang diekspresikan dalam bentuk kalimat yang signifikan dan mudah dimengerti. Sedangkan menurut Ani (2017), soal cerita adalah soal yang disajikan dalam bentuk cerita bermakna yang berhubungan dengan realita sehari-hari yang berdasarkan pada pengalaman belajar sebelumnya. Soal cerita matematika dapat diterapkan kepada siswa dengan tujuan untuk mencapai standar kompetensi yang telah ditetapkan oleh pemerintah, karena dapat melatih perkembangan proses bepikir secara berkelanjutan. Soal cerita matematika adalah masalah matematika yang dihubungkan dengan kehidupan untuk dicari solusinya menggunakan kalimat matematika yang mencakup bilangan, operasi hitung, dan relasi $(=,<,>, \leq, \geq)$ (Rahardjo dan Waluyati, 2011). Berdasarkan penjelasan di atas, dapat disimpulkan bahwa soal cerita matematika adalah soal matematika yang diekspresikan dalam bentuk kalimat yang signifikan dan mudah dimengerti yang berkaitan dengan kehidupan sehari-hari.

Sebuah soal matematika bisa menjadi masalah bagi satu siswa namun tidak untuk siswa lainnya. Suatu soal dipandang sebagai masalah jika soal tersebut bukan soal yang sering ditemukan siswa dan jawabannya tidak dapat diperoleh dengan mudah. Masalah dalam matematika dibagi menjadi dua jenis yaitu rutin dan tidak rutin (Charlesworth \& Lind dalam Dupe, 2015). Masalah rutin adalah masalah yang penyelesaiannya mengikuti pola yang dapat diprediksi dan diselesaikan dengan benar tanpa membaca keseluruhan pertanyaan dengan seksama, sedangkan masalah tidak rutin adalah masalah yang dalam penyelesaiannya terdapat lebih dari satu langkah dan pertanyaannya harus dibaca nengan seksama. Masalah rutin umumnya menggunakan prosedur matematika yang sama dengan yang sudah sering dipelajari, sedangkan masalah tidak rutin dalam penyelesaiannya memerlukan proses berpikir yang mendalam hingga dapat diselesaikan dengan prosedur yang benar. Dalam penelitian ini, soal cerita yang diberikan sebagai tes tulis merupakan soal cerita tidak rutin karena siswa tidak terbiasa dan masih kesulitan dalam menyelesaikannya.

Yang dimaksud kesalahan siswa dalam pemecahan soal cerita dalam penelitian ini adalah kekeliruan yang dilakukan siswa dalam menjawab soal cerita yang berhubungan dengan materi sistem persamaan linear tiga variabel.

Letak kesalahan adalah bagian dari pemecahan soal yang terjadi kekeliruan. Berdasar pada tahapan pemecahan masalah Polya, Indikator letak kesalahan siswa pada penelitian ini yaitu:

a) Salah dalam memahami soal (E1)

1. Salah menuliskan informasi yang diketahui dari soal

Siswa melakukan kesalahan ini apabila:

a. Tidak menuliskan informasi yang ada pada soal,

b. Tidak lengkap menuliskan informasi yang ada pada soal,

c. Salah menuliskan informasi yang ada pada soal.

2. Salah menuliskan apa yang ditanya dalam soal Siswa melakukan kesalahan ini apabila:

a. Tidak menulis informasi yang ditanyakan pada soal,

b. Tidak lengkap menulis informasi yang ditanyakan pada soal,

c. Salah menulis informasi yang ditanya dalam soal.

b) Salah dalam merencanakan penyelesaian (E2)

Siswa melakukan kesalahan ini apabila:

1. Tidak menuliskan pengandaian variabel yang digunakan untuk membuat model matematika,

2. Salah menuliskan variabel yang digunakan dalam membuat model matematika,

3. Tidak menulis model matematika,

4. Salah dalam menulis model matematika.

c) Salah dalam melaksanakan rencana penyelesaian (E3)

Siswa melakukan kesalahan ini apabila:

1. Tidak menuntaskan model matematika, 
2. Tidak memakai aturan matematika dalam menuntaskan model,

3. Salah ketika menuntaskan model matematika yang dibuat.

d) Kesalahan dalam memeriksa kembali (E4) Siswa melakukan kesalahan ini apabila:

1. Tidak menulis jawaban akhir soal,

2. Salah dalam menulis jawaban akhir soal,

3. Tidak lengkap menuliskan jawaban akhir soal,

Jenis kesalahan berhubungan dengan kesalahan dalam mengerjakan hitungan dan konsep penyelesaian soal. Sukirman (dalam Dupe, 2015) mengidentifikasi jenis kesalahan yang dilakukan oleh siswa dalam setiap aspek penguasaan bahan ajar matematika yaitu kesalahan konsep, kesalahan prinsip, dan kesalahan operasi. Uraian tentang indikator dari jenis kesalahan yang digunakan dalam penelitian ini yaitu:

a) Kesalahan konsep

Kesalahan konsep adalah kesalahan yang terkait dengan konsep yang digunakan dalam materi, indikatornya sebagai berikut:

1. Kesalahan dalam menafsirkan makna soal

2. Kesalahan dalam mengubah kalimat soal ke model matematika

3. Konsep variabel yang digunakan dalam pembuatan model matematika salah

4. Konsep metode yang digunakan dalam menyelesaikan soal salah

b) Kesalahan prinsip

Kesalahan prinsip adalah kekeliruan penggunaan aturan, rumus maupun prinsip yang berkaitan dengan materi, seperti menarik kesimpulan saat menentukan jawaban akhir.

c) Kesalahan operasi

Kesalahan operasi adalah kekeliruan saat melakukan perhitungan. Indikatornya kesalahan operasi adalah:

1. Salah dalam penggunaan aturan operasi atau perhitungan

2. Tidak teliti dalam berhitung

Faktor penyebab kesalahan adalah segala sesuatu yang dapat menyebabkan siswa melakukan kesalahan. Menurut Haji (dalam Dupe, 2015), ada dua faktor yang menyebabkan siwa melakukan kesalahan yaitu faktor kognitif dan non-kognitif. Faktor kognitif mencakup situasi terkait kemampuan intelektual dan cara siswa menguasai atau memproses materi matematika dalam pikirannya, seperti pemahaman siswa terhadap objek matematika yang berhubungan dengan materi soal cerita SPLTV. Sedangkan faktor non-kognitif adalah semua faktor di luar hal-hal yang berhubungan dengan kemampuan intelektual, seperti sikap, karakter, emosi, kebiasaan belajar, cara mengajar guru, fasilitas belajar, dan kondisi lingkungan. Dalam penelitian ini, faktorfaktor penyebab siswa melakukan kesalahan dalam setiap letak kesalahan yang dilakukan digali sejelas mungkin melalui wawancara.

\section{METODE PENELITIAN}

Penelitian ini termasuk dalam penelitian deskriptif kualitatif dengan jenis penelitian studi kasus. Tujuan penelian deskriptif kualitatif yaitu meneliti kondisi objek yang alamiah. Bogdan dan Taylor (1993) penelitian kualitatif adalah prosedur penelitian yang menimbulkan data deskriptif berupa kata-kata tertulis atau lisan secara komprehensif. Kualitatif berhubungan dengan aspek kualitas dan nilai atau arti yang terdapat di balik fakta. Arikunto (1986) mengemukakan bahwa studi kasus adalah penelitian yang dilakukan secara intensif dan mendalam terhadap individu, lembaga, atau gejala tertentu dengan daerah atau subjek yang sempit. Peneliti nantinya akan melakukan penelitian secara intensif dan mendalam kesalahan siswa dalam mengerjakan soal cerita SPLTV pada sebuah kelas. Yang dimaksud dengan penelitian deskriptif kualitatif dengan jenis penelitian studi kasus dalam penelitian ini adalah penelitian yang mengungkap, menganalisis, dan memberikan gambaran tentang letak kesalahan, jenis kesalahan, serta faktor penyebab kesalahan yang dilakukan oleh subjek penelitian secara rinci menggunakan tahapan pemecahan pemecahan masalah Polya. Kemudian hasil analisis akan menjadi deskripsi yang lengkap, sahih, nyata dan sistematis dari kesalahan yang dibuat siswa dalam memecahkan soal cerita materi SPLTV. Pada penelitian ini, instrumen utama yaitu peneliti sendiri. Sebagai instrumen utama, peneliti berinteraksi langsung dengan subjek penelitian.

Penelitian ini menggunakan metode tes tulis dan wawancara untuk mengumpulkan data. Tes tulis dilaksanakan oleh siswa yang telah memperoleh materi SPLTV di Sekolah. Peneliti memilih sumber data kelas XI IPA4 SMAN 1 Cerme. Dari 36 siswa, dipilih 3 dari hasil tes tulis yang dilakukan dengan teknik purposive sampling. Purposive sampling adalah teknik penentuan sampel dengan pertimbangan tertentu (Sugiyono, 2015). Data yang didapat pada berupa kesalahan-kesalahan siswa dalam menyelesaikan tes tulis soal cerita SPLTV. Dari hasil tes tulis, diperoleh tiga subjek penelitian. Pemilihan tiga subjek tersebut berdasarkan pertimbangan dapat membantu peneliti mendapatkan data yang diinginkan seperti siswa yang membuat kesalahan terbanyak, siswa yang melakukan kesalahan pada kedua soal yang diberikan, dan siswa yang bersedia untuk diwawancarai. Dari jawaban yang telah diberikan siswa, peneliti mendeskripsikan jenis dan letak kesalahan siswa dalam penyelesaian soal cerita SPLTV. Sedangkan faktor penyebab kesalahan diperoleh dari wawancara terhadap subjek penelitian. 
Analisis data yang digunakan dalam penelitian ini adalah prosedur analisis data kualitatif. Miles dan Huberman (dalam Sugiyono 2015) mengemukakan bahwa aktivitas dalam analisis data kualitatif dilakukan secara interaktif dan berlangsung terus menerus sampai tuntas. Data yang terkumpul selanjutnya dianalisis dengan prosedur reduksi data, penyajian data, serta menarik kesimpulan.

Untuk menguji keabsahan data, penulis menggunakan teknik Triangulasi. Moelong (dalam Azzahra dan Pujiastuti, 2020) menyebutkan bahwa teknik triangulasi adalah teknik pemeriksaan keabsahan data dengan memanfaatkan sesuatu yang lain sebagai pembanding data itu. Menurut Sugiyono (2015) triangulasi dibagi menjadi tiga yaitu triangulasi sumber yang dilakukan dengan cara mengecek data yang diperoleh melalui beberapa sumber, triangulasi teknik dilakukan cara mengecek data pada sumber yang sama dengan teknik yang berbeda, sedangkan triangulasi waktu dilakukan dengan mengumpulkan data pada waktu yang berbeda. Uji keabsahan data pada penelitian ini adalah triangulasi teknik. Data yang diperoleh dari hasil tes tulis dibandingkan dengan jawaban siswa pada saat wawancara sehingga data yang diperoleh akurat.

\section{HASIL DAN PEMBAHASAN}

Tes tulis yang diberikan dalam penelitian ini berupa soal cerita SPLTV sebanyak dua butir soal uraian yang dikerjakan secara individu dengan waktu pengerjaan 30 menit. Siswa melakukan kesalahan pada tahap pemecahan masalah yang berbeda-beda. Mulai dari salah dalam memahami makna soal, salah dalam menafsirkan soal ke bentuk matematika, salah dalam proses perhitungan. Kesalahan yang ditemukan peneliti di sebagian besar siswa adalah siswa tidak menuliskan apa yang ditanya dan jawaban akhir soal. Banyak siswa yang merasa kesulitan karena untuk menyelesaikan soal cerita matematika diperlukan keterampilan kognitif tingkat tinggi. Hal ini sejalan dengan Zewdie (2014), bahwa Pemecahan masalah termasuk keterampilan kognitif tingkat tinggi yang memerlukan regulasi dan koordinasi seperti visualisasi, abstraksi, pertanyaan, analisis, dan sintesis.

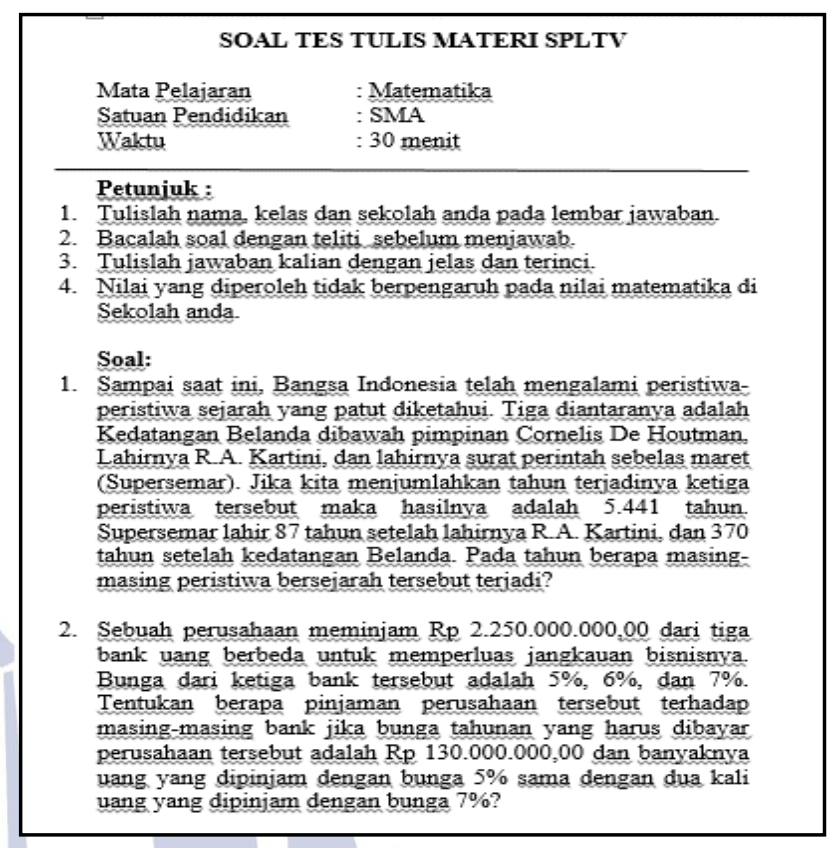

Gambar 1. Soal cerita SPLTV

Peneliti memilih kelas XI IPA4 SMAN 1 Cerme dengan jumlah siswa 36 sebagai sumber data. Untuk menentukan subjek penelitian, mereka diberikan tes tulis berupa dua soal cerita materi SPLTV. Hasil tes tulis tersebut kemudian dikoreksi dan ditentukan letak kesalahan yang dilakukan setiap siswa. Letak kesalahan siswa dilihat berdasarkan kesalahan yang mereka lakukan pada tahap pemecahan masalah Polya di antaranya: menuliskan informasi yang diketahui (T1), menuliskan informasi yang ditanya (T2), merencanakan penyelesaian (T3), melaksanakan rencana penyelesaian (T4), dan memeriksa kembali jawaban (T5). Dari hasil tes tulis, diketahui bahwa siswa melakukan kesalahan pada T1 sebanyak 15,53\%; T2 26,30\%; T3 15,94\%; T4 16,73\%; da T5 sebanyak $25,10 \%$. Tiga subjek penelitian kemudian dipilih berdasarkan hasil tes tulis dengan kriteria siswa yang membuat kesalahan terbanyak, siswa yang melakukan kesalahan pada kedua soal yang diberikan, dan siswa yang bersedia untuk diwawancarai. Ketiga siswa yang menjadi subjek penelitian adalah AE dengan kode subjek SP1, IW dengan kode subjek SP2, dan RAR dengan kode subjek SP3. Subjek penelitian yang terpilih disajikan berikut.

Tabel 1. Subjek penelitian terpilih

\begin{tabular}{|c|c|c|c|c|}
\hline Kode & $\begin{array}{c}\text { Letak } \\
\text { Kesalahan } \\
\text { Soal No. } 1\end{array}$ & $\begin{array}{c}\text { Letak } \\
\text { Kesalahan } \\
\text { Soal No. } 2\end{array}$ & Jumlah & $\begin{array}{l}\text { Kode } \\
\text { Subjek }\end{array}$ \\
\hline $\mathrm{AE}$ & $\begin{array}{l}\text { T1, T2, T3, } \\
\text { T4, dan T5 }\end{array}$ & $\begin{array}{l}\mathrm{T} 2, \mathrm{~T} 4, \\
\text { dan T5 }\end{array}$ & 8 & SP1 \\
\hline IW & $\begin{array}{l}\text { T1, T2, T3, } \\
\text { T4, dan T5 }\end{array}$ & $\begin{array}{c}\text { T2, T3, } \\
\text { T4, dan } \\
\text { T5 }\end{array}$ & 9 & SP2 \\
\hline
\end{tabular}




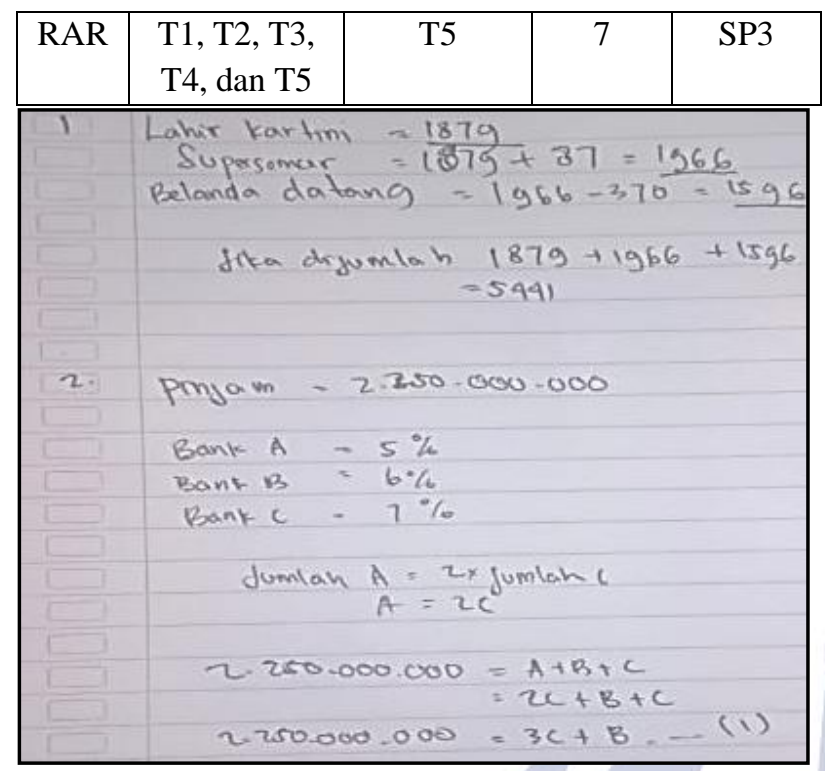

Gambar 2. Jawaban SP1

Widdiharto (2008) mengatakan bahwa pada tahaptahap pemecahan masalah matematika yang berbentuk uraian, siswa melakukan kegiatan intelektual yang dituangkan pada kertas pekerjaan, dari kertas pekerjaan dapat dilihat letak dan jenis kesalahan yang dilakukan. Data hasil tes tulis yang diperoleh sudah dapat digunakan untuk menentukan letak dan jenis kesalahan SP1, namun belum cukup untuk mengetahui faktor penyebab kesalahan yang dilakukan, sehingga harus dilakukan wawancara kepada SP1.

Dari hasil wawancara yang diperoleh, dapat diketahui bahwa SP1 kesulitan mengerjakan soal nomor 1 karena tidak paham dengan soal yang diberikan sebab tidak terbiasa mengidentifikasi dan menulis kembali informasi yang diketahui dan ditanya sehingga menyebabkan kesalahan pemahaman terhadap soal dan salah dalam pengerjaannya. Jawaban yang dituliskan oleh SP1 berasal dari pengetahuannya saat mempelajari mata pelajaran Sejarah dan bukan dari pengerjaan menggunakan prosedur penyelesaian soal cerita. Sedangkan pada nomor 2, SP1 mengatakan paham apa yang dimaksud dari soal cerita yang diberikan dan apa yang ditanyakan, namun masih merasa kesulitan membuat persamaannya dan bingung apakah harus menggunakan metode subtitusi atau eliminasi terlebih dahulu dalam menyelesaikan soal. Selain itu SP1 juga terburu-buru dalam mengerjakan tanpa memahami tahap-tahap mengerjakan soal cerita dan konsep yang digunakan dalam pengerjaan.

Untuk mengetahui lebih jelas letak, jenis dan faktor penyebab kesalahan, maka peneliti melakukan wawancara terhadap SP1 dengan P sebagai peneliti.

P : Dari jawaban nomor 1, kamu menulis Kartini lahir tahun 1879. Apa informasi tersebut ada pada soal? SP1 : Um... Tidak mbak.

P : Kamu tahu darimana kalau Kartini lahir tahun 1897 ?
SP1 : Tau saja, mbak. Kan diperingati setiap tahun.

P : Untuk mengerjakan soal cerita, gunakan informasi yang ada pada soal. Tidak boleh langsung menjawab seperti itu.

SP1 : Iya, mbak.

$\mathrm{P}$ : Coba ceritakan bagaimana kcara kamu mengerjakan nomor 1 !

SP1 : Supersemar lahir 87 tahun setelah Kartini jadinya $1987+87=1966$. Terus Kalau Belanda datangnya 370 tahun sebelum Supersemar, 1966-370= 1596, mbak.

$\mathrm{P} \quad$ : Kenapa kamu tiba-tiba menulis seperti itu? Kenapa tidak menuliskan apa yang diketahui dan ditanya agar paham maksud soal, diubah ke bentuk matematika, kemudian dikerjakan?

SP1 : Um... Lupa, mbak. Buru-buru, males nulis lagi.

$\mathrm{P}$ : Apa waktunya kurang?

SP1 : Enggak mbak.

$\mathrm{P} \quad$ : Kenapa kamu tidak menggunakan cara pengerjaan soal cerita?

SP1 : Nggak tau mau diapakan, mbak. Jadi aku jawab sebisanya.

P : Apakah kamu mengerti apa yang diketahui dan ditanya pada nomor 2 ?

SP1 : Iya, mbak.

$\mathrm{P} \quad$ : Bagaimana kamu mendapatkan persamaan 1 ?

SP1 : Total pinjamannya $\mathrm{A}+\mathrm{B}+\mathrm{C}=2.250 .000 .000$ terus nilai A dua kali nilai $\mathrm{C}$, jadi aku ganti A dengan $2 \mathrm{C}$, mbak. Terus ditambah.

$\mathrm{P}$ : Kenapa tidak diteruskan setelah mendapatkan persamaan 1 ?

SP1 : Nggak bisa cari nilai A, B dan C, mbak.

Berdasarkan hasil wawancara diatas, diketahui bahwa SP1 tidak terbiasa dalam mengidentifikasi dan menulis kembali apa yang diketahui dan ditanyakan menyebabkan kesalahan yang dilakukan oleh subjek. Selain itu, ada faktor penyebab lain, siswa terlalu terburu-buru dalam mengerjakan soal dan kurang memahami langkah-langkah mengerjakan soal cerita secara sistematis sehingga salah dalam memahami. Sebanding dengan penelitian Dupe (2015) bahwa siswa melakukan kesalahan karena bingung dan belum memahami maksud soal, menyebabkan terjadinya kesalahan pada langkah pengerjaan selanjutnya dan juga prestasi di Kelas. hal ini searah dengan Hasan (2020) bahwa pemahaman konsep dan kemampuan proses dalam matematika akan mempengaruhi kemampuan pemecahan masalah.

Berdasarkan hasil tes tulis dan wawancara, diperoleh letak, jenis, dan faktor penyebab kesalahan SP1, hasil analisis kesalahan SP1 dirangkum sebagai berikut. 
Tabel 2. Hasil analisis kesalahan SP1

\begin{tabular}{|c|c|c|c|}
\hline $\begin{array}{l}\text { No } \\
\text { Soal }\end{array}$ & $\begin{array}{c}\text { Letak } \\
\text { Kesalahan }\end{array}$ & $\begin{array}{c}\text { Jenis } \\
\text { Kesalahan }\end{array}$ & Penyebab Kesalahan \\
\hline 1 & $\begin{array}{l}\text { a. E1 } \\
\text { b. E2 } \\
\text { c. E3 } \\
\text { d. E4 }\end{array}$ & $\begin{array}{l}\text { a. Konsep } \\
\text { b. Prinsip } \\
\text { c. Operasi }\end{array}$ & $\begin{array}{l}\text { a. Tidak memahami } \\
\text { informasi dalam } \\
\text { soal } \\
\text { b. Tidak mampu } \\
\text { mengubah kalimat } \\
\text { soal ke model } \\
\text { matematika } \\
\text { c. Lemah dalam } \\
\text { konsep variabel }\end{array}$ \\
\hline 2 & $\begin{array}{l}\text { a. E1 } \\
\text { b. E3 } \\
\text { c. E4 }\end{array}$ & $\begin{array}{l}\text { a. Konsep } \\
\text { b. Prinsip } \\
\text { c. Operasi }\end{array}$ & $\begin{array}{l}\text { a. Lemah dalam } \\
\text { konsep variable } \\
\text { b. Tidak mengerti } \\
\text { tentang metode } \\
\text { eliminasi, } \\
\text { subtitusi, dan } \\
\text { determinan }\end{array}$ \\
\hline
\end{tabular}

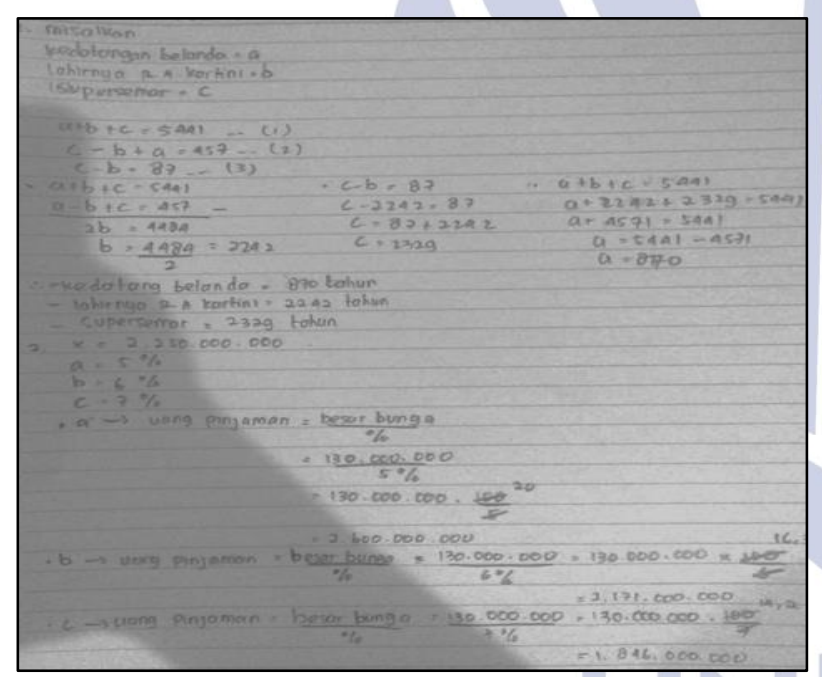

Gambar 3. Jawaban SP2

Untuk mengetahui lebih jelas letak, jenis dan faktor kesalahan, maka peneliti melakukan wawancara terhadap SP2.

$\mathrm{P}$ : Apakah kamu paham apa yang diketahui dan ditanya pada soal nomor 1 ?

SP2: Iya, mbak.

$\mathrm{P}$ : Kenapa tidak ditulis?

SP2 : Biasanya juga gitu, mbak. Langsung dikerjakan.

P : Jangan dibiasakan ya. Lain kali harus ditulis, dalam mengerjakan soal cerita prosedurnya harus lengkap.

SP2 : Iya, mbak.

P :Coba kamu lihat persamaan 2, apa sudah sesuai sama pernyataan "Supersemar lahir 370 tahun setelah kedatangan Belanda?

SP2 : ... Eh, harusnya $c-a=370$ ya, mbak. Soalnya kemarin jawabanku dari masa depan semua, hehe.
P : Apakah kamu paham maksud dari soal nomer 2 dan sudah yakin dengan jawabanmu?

SP2: Soalnya sih paham, ngerjainnya yang susah. Bingung bikin persamaannya. Soalnya nggak pernah ketemu soal seperti itu.

$\mathrm{P} \quad$ : Biasanya kamu mengerjakan soal seperti apa?

SP2: Ya soal biasa langsung pakai angka, mbak. Jarang dapat yang cerita. Biasanya juga kalau latihan soal dikerjakan sama-sama di papan tulis, kalo ga tau bisa tanya. Sekarang biasanya habis materi terus dikasih tugas mandiri, mbak.

Dari wawancara, dapat disimpulkan bahwa SP2 penyebab siswa melakukan kesalahan adalah kurang memahami dalam mengubah informasi yang ada pada soal ke model matematika sehingga terjadi kesalahan. Kesalahan tersebut terjadi karena kurang melatih kemampuan pemecahan masalah terutama pada soal tidak rutin, sehingga siswa kurang terampil dalam memanipulasi dan berpengaruh dalam kemampuannya membuat model matematis. Hal ini sejalan dengan penelitian yang dilakukan Rohmah dan Sutiarto (2018) yang menyatakan bahwa penyebab kesalahan siswa adalah belum memahami mengubah soal ke bentuk matematika, siswa tidak memahami materi secara lengkap, dan kurangnya pengalaman dalam mengerjakan soal. SP2 juga tidak terbiasa menggunakan prosedur penyelesaian soal cerita.

Dari hasil tes tulis dan wawancara, diperoleh letak, jenis, dan faktor penyebab kesalahan SP2, hasil analisis kesalahan SP2 dirangkum sebagai berikut:

Tabel 3. Hasil analisis kesalahan SP2

\begin{tabular}{|c|c|c|c|}
\hline No & & & Penyebab Kesalahan \\
\hline Soal & Kesalahan & Kesalahan & \\
\hline 1 & $\begin{array}{l}\text { a. E1 } \\
\text { b. E2 } \\
\text { c. E3 } \\
\text { d. E4 }\end{array}$ & $\begin{array}{l}\text { a. Konsep } \\
\text { b. Prinsip } \\
\text { c. Operasi }\end{array}$ & $\begin{array}{l}\text { a. Lemah dalam } \\
\text { mengubah kalimat } \\
\text { soal ke dalam model } \\
\text { matematika } \\
\text { b. Kurang teliti dalam } \\
\text { mengerjakan soal }\end{array}$ \\
\hline 2 & $\begin{array}{l}\text { a. E1 } \\
\text { b. E2 } \\
\text { c. E3 } \\
\text { d. E4 }\end{array}$ & $\begin{array}{l}\text { a. Konsep } \\
\text { b. Prinsip } \\
\text { c. Operasi }\end{array}$ & $\begin{array}{l}\text { a. Lemah dalam } \\
\text { mengubah kalimat } \\
\text { soal ke dalam model } \\
\text { matematika } \\
\text { b. Kurang teliti dalam } \\
\text { mengerjakan soal }\end{array}$ \\
\hline
\end{tabular}




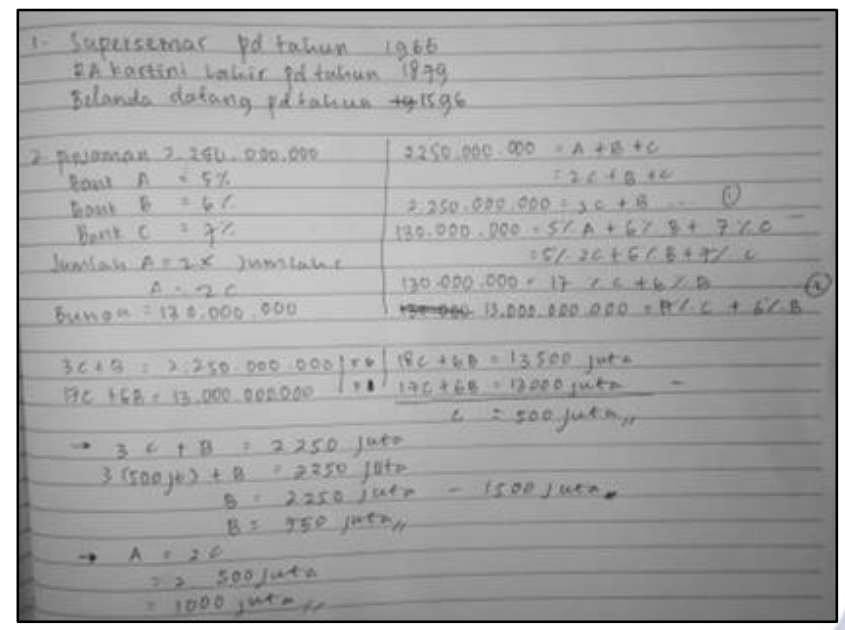

Gambar 4. Jawaban SP3

Berikut kutipan wawancara yang dilakukan pada SP3 untuk mengetahui lebih jelas letak, jenis dan faktor kesalahan.

$\mathrm{P}$ : Coba ceritakan jawaban kamu untuk nomer 1!

SP3 : Supersemar lahir tahun 1996, Kartini 1878, terus Belanda 1596. Benar nggak mbak?

$\mathrm{P}$ : Betul. Bagaimana cara menemukan jawabannya?

SP3 : Eh... Aku ingat-ingat saja tahun kejadiannya mbak.

$\mathrm{P}$ : Apa kamu paham sama soal cerita nomor 1, apa saja yang diketahui?

SP3 : Um... Nggak juga.

$\mathrm{P} \quad$ : Kenapa tidak kamu tuliskan apa yang diketahui dan ditanya?

SP3 :Bingung, mbak. Nggak tau mau diapakan angkaangkanya. Jadi aku jawab langsung saja.

P :Kemudian nomor 2, apa ada kesulitan dalam memahami soal?

SP3 :Enggak mbak.

$\mathrm{P}$ :Apa kamu sudah yakin dengan jawabannya?

SP3 :Um... Inshaallah.

$\mathrm{P}$ :Dari pekerjaan kamu, mana yang menunjukkan jawaban soal nomor 2?

SP3 :A= 1000 juta, $B=750$ juta, terus $C=500$ juta.

$\mathrm{P} \quad$ :Itu baru hasil perhitungannya. Dalam mengerjakan soal cerita, kamu harus membuat kesimpulan dari jawaban kamu.

SP3 :Oh iya lupa, mbak. Kemarin buru-buru.

$\mathrm{P} \quad$ : Kenapa bisa lupa? Apa waktunya kurang?

SP3: Enggak kok mbak, hehe. Kemarin di rumah lagi banyak orang. Terus biasanya hanya sampai hitungan saja sudah selesai, nggak pakai kesimpulan.

SP3 melakukan kesalahan dalam pemahaman soal nomor 1 yaitu tidak dapat menuliskan apa yang diketahui dan ditanyakan dalam soal sehingga menebabkan SP3 salah dalam pengerjaannya. Hal ini sejalan dengan Rahayu (2018) bahwa pada saat membaca soal cerita, siswa masih melakukan kesalahan yang ditunjukkan dengan salah dalam membaca perintah pada soal. Sedangkan pada soal nomor 2, SP3 tidak mengalami kesulitan dalam memahami soal. Begitu juga pada tahap merencanakan dan menjalankan rencana penyelesaian. Namun, siswa melakukan kesalahan yaitu tidak menuliskan solusi atau tidak menyimpulkan jawaban dari pertanyaan soal. Berdasarkan hasil tes dan wawancara, penyebabnya adalah SP2 tidak terbiasa dalam menjawab soal dengan menyimpulkan hasil jawabannya. Hal ini sejalan dengan Dupe (2015) bahwa gagalnya siswa menjawab pertanyaan dengan benar karena kurangnya dalam penafsiran dan menggunakan metode yang tepat, selain itu juga ada faktor kurangnya pengalaman dalam menyelesaikan masalah. Dari hasil tes tulis dan wawancara, diperoleh letak, jenis, dan faktor penyebab kesalahan SP3, hasil analisis kesalahan SP3 dirangkum sebagai berikut:

Tabel 4. Hasil Analisis Kesalahan SP3

\begin{tabular}{|c|c|c|c|}
\hline $\begin{array}{l}\text { No } \\
\text { Soal }\end{array}$ & $\begin{array}{c}\text { Letak } \\
\text { Kesalahan }\end{array}$ & $\begin{array}{c}\text { Jenis } \\
\text { Kesalahan }\end{array}$ & Penyebab Kesalahan \\
\hline 1 & $\begin{array}{l}\text { a. E1 } \\
\text { b. E2 } \\
\text { c. E3 } \\
\text { d. E4 }\end{array}$ & $\begin{array}{l}\text { a. Konsep } \\
\text { b. Prinsip } \\
\text { c. Operasi }\end{array}$ & $\begin{array}{l}\text { a. Tidak memahami } \\
\text { informasi pada soal. } \\
\text { b. Lemah dalam } \\
\text { mengubah kalimat } \\
\text { soal ke dalam model } \\
\text { matematika } \\
\text { c. Kurang teliti dalam } \\
\text { mengerjakan soal }\end{array}$ \\
\hline 2 & $\begin{array}{l}\text { a. E1 } \\
\text { b. E2 } \\
\text { c. E3 } \\
\text { d. E4 }\end{array}$ & a. Prinsip & $\begin{array}{l}\text { a. Kurang teliti dalam } \\
\text { mengerjakan soal }\end{array}$ \\
\hline
\end{tabular}

Hasan (2020) menyatakan bahwa kesalahan siswa SMA dalam menyelesaikan soal yang berkaitan SPLTV terletak pada kesalahan membaca atau reading error (tidak dapat mengenali symbol atau kata kunci dengan tepat), kesalahan transformasi atau transformation error (tidak dapat operator matematika dan prosedur yang diperlukan), dan kesalahan proses atau process skill error (tidak bisa memproses soal dengan benar). Kesalahan tersebut dikarenakan siswa tidak memahami arti soal, tidak fokus atau salah pada tahap sebelumnya, dan tidak memahami konsep hitung operasi aljabar.

Dari hasil analisis kesalahan kelas XI IPA4 SMAN 1 Cerme dalam penyelesaian soal cerita materi SPLTV, diketahui letak kesalahan, jenis kesalahan, serta faktor penyebab siswa melakukan kesalahan yaitu:

1. Letak kesalahan yang dilakukan siswa

Dari hasil tes tulis, dapat diketahui bahwa kesalahan yang terjadi yaitu pada tahap memahami soal), merencanakan peyelesaian, melaksanakan 
rencana penyelesaian masalah, dan memeriksa kembali. Sehingga dalam penelitian ini, kesalahan yang dilakukan siswa ketika menyelesaikan soal cerita SPLTV terletak pada keempat tahap pemecahan masalah Polya (1973), yang diuraikan sebagai berikut:

\section{a. Kesalahan memahami soal}

Kesalahan yang sering terjadi pada tahap memahami soal di antaranya tidak dapat menuliskan apa yang diketahui dan ditanya dalam soal cerita melainkan langsung ke tahap kedua yaitu merencanakan penyelesaian. Ada pula siswa yang salah dalam menuliskan apa saja informasi yang diketahui dan ditanyakan dalam soal sehingga menyebabkan terjadi kesalahan pada tahap-tahap penyelesaian soal cerita selanjutnya. Kesalahan dalam menuliskan apa yang diketahui dan ditanya ini banyak terjadi pada penyelesaian soal cerita nomor 1 .

b. Kesalahan dalam merencanakan penyelesaian

Pada tahap ini, banyak siswa yang tidak menuliskan pemisalan variabel sehingga menghambat mereka untuk mengerjakan soal cerita tersebut. Beberapa siswa juga melakukan kesalahan pada saat mengubah kalimat soal ke dalam model matematika. Sehingga kesalahan juga terjadi pada saat mereka menyelesaikan perhitungan.

c. Kesalahan dalam melaksanakan rencana penyelesaian

kesalahan yang ditemukan antara lain siswa tidak mengerjakan model matematika yang telah mereka dapatkan sebelumya. Hal ini dikarenakan lemahnya pemahaman mereka mengenai metodemetode yang dapat digunakan untuk menyelesaikan soal SPLTV. Ada pula siswa yang melakukan kesalahan dalam perhitungan karena kurang cermat dalam pengerjaan soal sehingga terjadi kesalahan dalam menuliskan hasil akhir penyelesaian.

d. Kesalahan dalam memeriksa kembali

Tahap terakhir dalam penyelesaian soal cerita yaitu memeriksa kembali. Sebagian besar siswa yang di tes melakukan kesalahan pada tahap ini karena tidak menuliskan jawaban akhir dari penyelesaian soal cerita yang diberikan.

2. Jenis kesalahan yang dilakukan siswa penelitian

Jenis kesalahan yang dilakukan siswa dalam penyelesaian tes tulis yang diberikan beragam di antaranya:

a. Kesalahan konsep

Kesalahan konsep dalam penelitian ini merupakan kesalahan yang berhubungan dengan konsep-konsep yang digunakan dalam materi SPLTV. Kesalahan konsep yang dilakukan yaitu kesalahan dalam mengubah informasi pada soal ke dalam model matematika, konsep variabel yang digunakan dalam pembuatan matematika salah, serta salah konsep mengenai metode eliminasi, subtitusi, dan determinan.

b. Kesalahan prinsip

Kesalahan yang dilakukan siswa pada tes tulis ini yaitu salah dalam penggunaan prinsip yang berkaitan dengan materi, terutama metode yang digunakan untuk penyelesaian soal cerita SPLTV.

\section{c. Kesalahan operasi}

Pada tes tulis, siswa melakukan kesalahan dalam pengoperasian atau perhitungan. Hal ini disebabkan karena kurang teliti dalam mengerjakan serta kurangnya pemahaman terhadap metode eliminasi, subtitusi, dan determinan yang digunakan.

3. Faktor penyebab kesalahan subjek penelitian

Dilihat dari hasil tes tulis dan wawancara yang dilakukan, maka faktor penyebab kesalahan siswa dalam menyelesaikan soal cerita dibagi menjadi dua yaitu

a. Faktor kognitif

Faktor kognitif meliputi keadaan yang berkaitan dengan kemampuan intelektual dan cara siswa memahami materi dalam penalaran mereka, seperti pemahaman terhadap objek matematika yang berhubungan dengan soal cerita SPLTV. Kesulitan-kesulitan yang dihadapi siswa saat menyelesaikan soal cerita SPLTV juga dapat mengakibatkan siswa membuat kesalahan. Hal ini sejalan dengan Dupe (2015) bahwa kesulitan merupakan penyebab terjadinya kesalahan. Faktor kognitif yang berpengaruh dalam penelitian ini diantaranya: Tidak memahami informasi dalam soal cerita, Tidak mampu mengubah soal ke model matematika, Lemah dalam konsep variabel, Tidak paham tentang metode-metode yang digunakan dalam memecahkan soal SPLTV dan kurang teliti dalam mengerjakan soal.

b. Faktor non-kognitif

Faktor non-kognitif yang diperoleh dalam wawancara yang dilakukan antara lain cara belajar dan kondisi lingkungan. Siswa sudah terbiasa belajar di Sekolah merasa kesulitan dan kewalahan apabila pembelajaran dilakukan secara online. Saat di sekolah, mereka belajar dibimbing oleh guru, dengan belajar secara online, mereka harus berusaha untuk memahami 
suatu materi secara mandiri yang hasilnya belum tentu maksimal. Suasana belajar di rumah juga jauh berbeda dengan belajar di ruang kelas yang kondusif.

\section{PENUTUP}

\section{Simpulan}

Dari penelitian yang telah dilakukan dapat disimpulkan bahwa dalam menyelesaikan soal cerita SPLTV, siswa melakukan kesalahan di setiap tahap pemecahan masalah. Pada tahap memahami masalah siswa belum sepenuhnya memahami soal yang diberikan. Mereka tidak dapat mengidentifikasi informasi pada soal atau pun apa yang ditanyakan soal. Letak kesalahan yang dilakukan siswa selanjutnya adalah merencanakan penyelesian. Ada yang tidak tepat dalam menuliskan pemisalan variabel dan model matematika, ada siswa yang salah. Ada sebagian siswa yang mampu menuliskan pemisalan variabel dan model matematika namun melakukan kesalahan pada saat menyelesaiakan model matematika atau persamaan yang telah mereka buat. Hal ini dikarenakan lemahnya pemahaman mereka terhadap materi SPLTV dan perhitungan sehingga tidak menemukan solusi yang tepat. Kesalahan yang sering dilakukan siswa pada saat menyelesaikan soal cerita adalah tidak menulis kesimpulan atau memeriksa kembali jawaban mereka apakah hasil akhir yang mereka peroleh sudah sesuai dengan apa yang ditanyakan pada soal.

Jenis kesalahan yang dilakukan siswa dalam penelitian ini yaitu kesalahan konsep, kesalahan prinsip, dan kesalahan operasi. Kesalahan konsep yang terjadi yakni variabel yang digunakan untuk membuat model matematika tidak tepat, serta salah dalam menggunakan metode subtitusi, eliminasi ataupun determinan dalam mengerjakan soal. Kesalahan prinsip yang dilakukan siswa yaitu salah dalam memahami dan menggunakan aturan-aturan matematika yang berhubungan dengan materi terutama metode yang digunakan dalam menyelesaikan soal cerita SPLTV. Sedangkan kesalahan operasi yang dilakukan siswa dalam tes tulis adalah salah dalam pengoperasian atau perhitungan.

Dari penelitian yang dilakukan, diketahui bahwa faktor penyebab terjadinya kesalahan saat siswa menyelesaiakan soal cerita yang diberikan yaitu dari kemampuan kognitif siswa sendiri seperti tidak mengerti apa saja yang diketahui dan ditanyakan dalam soal,tidak mengerti cara mengubah kalimat soal ke model matematika, lemah dalam konsep variabel dan tidak paham tentang metode-metode yang digunakan dalam menyelesaikan soal SPLTV. Selain faktor kognitif, kesalahan-kesalahan tersebut juga dipengaruhi gaya belajar siswa dan kondisi lingkungan siswa.

\section{Saran}

Hasil penelitian ini diharapkan dapat menjadi masukan bagi pendidik guna meningkatkan kemampuan matematika siswa pada materi SPLTV. Saran yang dapat penulis sumbangkan dalam penelitian ini diantaranya: Untuk mengatasi kesalahan dalam memahami soal, dalam pembelajaran guru sebaiknya memberikan berbagai contoh konkret dalam realita sehari-hari, menginstruksikan siswa untuk membaca soal dengan teliti dan membiasakan siswa untuk menuliskan apa ysng diketahui dan ditanyakan dalam soal untuk mempermudah penyelesaian. Selain itu guru juga perlu membiasakan siswa mengerjakan yang bervariasi. Untuk mengatasi kesalahan dalam membuat rencana penyelesaian, guru sebaiknya meningkatkan kemampuan siswa dalam membuat pemisalan variabel dan mengubah kalimat soal ke dalam bentuk matematika dengan cara membiasakan siswa mengerjakan soal cerita. Untuk mengatasi kesalahan siswa dalam melaksanakan rencara penyelesaian, guru sebaiknya meningkatkan pemahaman konsep siswa terhadap materi SPLTV, metode eliminasi, subtitusi, dan determinan. Serta membiasakan siswa untuk mengerjakan soal SPLTV dengan menggunakan metode yang sesuai. Untuk mengatasi kesalahan pada memerika kembali jawaban akhir, guru sebaiknya meminta siswa untuk melihat kembali hasil pekerjaan mereka, apakah hasil yang didapat sudah sesuai dengan apa yang diminta soal, serta membiasakan siswa untuk mengerjakan soal secara lengkap.Untuk menanggulangi kesalahan-kesalahan yang dilakukan siswa dalam mengerjakan soal cerita, guru sebaiknya memperkuat konsep matematika terkait dengan materi yang diajarkan, menjelaskan kepada siswa aplikasi dari materi tersebut dalam kehidupan, serta membiasakan siswa untuk menyelesaikan soal matematika.

\section{DAFTAR PUSTAKA}

Ani, E. U., 2017. Profil Kemampuan Pemecahan Masalah Matematika Siswa Berbentuk Soal Cerita Materi Bangun Ruang. Tesis Tidak diterbitkan. Surabaya: PPs Universitas Negeri Surabaya

Arikunto, S. 1986. Prosedur penilaian, Jakarta, Bina Aksara

Atim, Mohammad. 2008. Analisis Kesalahan Siswa Dalam Menyelesaikan Soal Terapan Sistem Persamaan Linear Dua Variabel Di Kelas X MAN Gresik. Tesis Tidak diterbitkan. Surabaya: PPs Universitas Negeri Surabaya.

Azzahra, R. H., \& Pujiastuti, H., 2020. Analisis Kemampuan Pemecahan Masalah Siswa pada Materi SPLTV.Jurnal Pendidikan Matematika dan Matematika, 4(1):153-162.

Bogdan, R. dan S.J. Taylor. 1993. Dasar-dasar Penelitian Kualitatif. (A. Khozin Afandi Penerjemah). Surabaya: Usaha Nasional. 
Dupe, M. J., 2015. Analisis Kesalahan Siswa SMP dalam Menyelesaikan Soal Cerita Bangun Datar. Tesis Tidak diterbitkan. Surabaya: PPs Universitas Negeri Surabaya.

Hasan, N. W., 2020. Analisis Kesalahan Peserta Didik SMA Al-Mizan Surabaya dalam Menyelesaikan Soal Cerita Sistem Persamaan Linear Tiga Variabel. Skripsi tidak diterbitkan. Surabaya: Universitas Negeri Surabaya.

Kemdikbud. (2020). Pusat Penilaian Pendidikan. (https://hasilun.puspendik.kemdikbud.go.id/\#2019!s ma!daya serap!99\&99\&999!a\&03\&T\&T\&1\&!1!\& diaksespada tanggal 16 Desember 2020)

Kuswanti, Yayuk. 2018. Deskripsi Kesalahan Siswa pada Penyelesaian Masalah SPLTV. Tesis tidak dipublikasikan. Malang: Universitas Negeri Malang.

Loc, N.P \& Hoc, T.C.T.2014."A Survey of 12th Grade Students' Errors in Solving Calculus Problems". Makalah disajikan dalam International Journal of Scientific \& Technology Research. Vol.3(6):hal 1-2.

Polya, G. 1973. How to solve it. 2nd penyunt. New Jersey: Princeton Science Library.

Rahardjo, M. \& Waluyati, A., 2011. Pembelajaran Soal Cerita Hitung Campuran di Sekolah Dasar. Yogyakarta: PPPPTK Matematika.

Rahayu, P. 2018. Analisis Kesalahan Siswa SMP dalam Menyelesaikan Soal SPLDV. Prosiding Seminar Nasional Pendidikan Matematika Etnomatnesia. Yogyakarta: Universitas Negeri Yogyakarta.

Rohmah, M., \& Sutiarso, S. 2018. Analysis Problem Solving in Mathematical Using Theory Newman. EURASIA Journal of MathematicsScience and Technology Education,14(2):671-681.

Rosyidi, A. H., 2005. Analisis Kesalahan Siswa Kelas II Mts Al-Khoriyah Dalam Menyelesaikan Soal Cerita Yang Memuat Soal Cerita dengan Sistem Persamaan Linear Dua Peubah. Tesis tidak diterbitkan. Surabaya: Perpustakaan Pasca Sarjana Unesa.

Soedjadi, R. 2000. Kiat Pendidikan Matematika di Indonesia. Jakarta: Direktorat Jenderal Pendidikan Tinggi Departemen Pendidikan Nasional.

Sudijono, A. 2011. Pengantar Evaluasi Pendidikan. Jakarta: Raja Grafindo Persada.

Sugiyono. 2015. Metode Penelitian Kombinasi (Mix Methods). Bandung: Alfabeta.

Utami, A. J. L., \& Zulkanaen, R. 2018. Analisis Kesalahan Siswa Kelas XI Dalam Menyelesaikan Soal Cerita Pada Materi Sistem Persamaa Linear Tiga Variabel
(SPLTV). Prosiding Seminar Nasional Pendidikan Matematika. Karawang: USINKA

White, A. L., 2005. Active Mathematics In Classrooms Finding Out Why Children Make Mistakes And Then Doing Something To Help Them. Square One, December, 15(4), pp. 15-19.

Widdiharto, Rachmadi. 2008. Diagnosis Kesulitan Belajar Siswa Matematika SMP Dan Alternatif Proses Remidinya. Yogyakarta: Kementrian pendidikan Nasional.

Zewdie, Z. M., 2014. An Investigation of Students' Approaches to Problem Solving I Psysics Courses. Vol. 2, No. 1: 77-89.

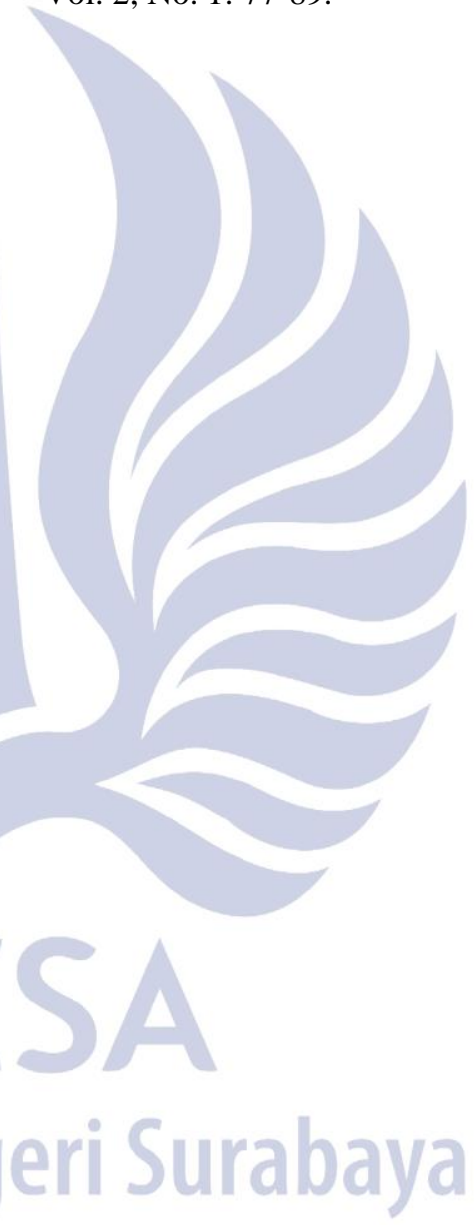

